REVIEW ARTICLE

\title{
TWO PERSPECTIVES ON THE RECENT WAR IN IRAQ
}

Tobie Beukes

Centre for Military Studies, Stellenbosch University.

- Ashcroft, J. 2010. Making a killing: The explosive story of a hired gun in Iraq. London: Virgin Books. Paperback, 338 pages, ISBN 9780753512340.

- $\quad$ Ashcroft, J. 2009. Escape from Baghdad. London: Virgin Books. Paperback, 301 pages, ISBN 9780753519844.

- Johnson, KW. 2013. To be a friend is fatal: The fight to save the Iraqis America left behind. New York: Scribner. Hardcover, 338 pages, ISBN 9781476710488 .

\section{Introduction}

The three books discussed here can all be classified as memoirs or even as auto-ethnographies. The two authors relate how they experienced the recent armed conflict in Iraq. The narratives of both authors include detailed accounts of the extraordinary efforts they made to help Iraqi friends leave the country. Although Ashcroft and Johnson view the war from two very different perspectives, their narratives complement each other and can be read together profitably. Researchers and scholars with a focus on contemporary armed conflict should nevertheless find them well worth reading. This review explains why.

\section{Ashcroft's books}

Making a killing: The explosive story of a hired gun in Iraq is James Ashcroft's first book and Escape from Baghdad, his second. Ashcroft employs a

Scientia Militaria, South African Journal of Military Studies, Vol 43, No. 2, 2015, pp. 187-198. doi : $10.5787 / 43-2-1130$ narrative style typically associated with entertainment as purpose and the general public as target audience. He wrote both books with the aid of a ghost writer, Clifford Thurlow. 
In his first book, Ashcroft focuses on his tour of duty in Iraq with a UKbased private military security company (PMSC) called Spartan, from 2003 to 2005. Spartan had won a contract to train a guard force of 1500 Iraqis for the protection of water supply infrastructure. Ashcroft was a member of the team of former British Army soldiers ${ }^{1}$ employed as trainers.

Ashcroft's second book is a sequel to the first. It is a personal account of his participation in an attempt to rescue a former Spartan comrade and his family from Baghdad in 2007. The former comrade, Assam ('Sammy') Mashoen, is an Iraqi national who had been employed by Spartan as chief translator for the guard-force training programme. Sammy's name had been entered in a Shia death list and he was actively being hunted at the time. ${ }^{2}$

\section{Kirk Johnson's book}

To be a friend is fatal: The fight to save the Iraqis America left behind is Kirk Johnson's first book. It is a personal narrative told in non-chronological order. Part of the book deals with Johnson's experiences as an employee of the United States Agency for International Development (USAID) in Iraq during 2005. Most of the book, however, is devoted to Johnson's experiences after an accident had ended his USAID career and forced his return to the United States. In this part, Johnson describes his efforts to obtain visas for US-affiliated Iraqi nationals. Johnson's book also contains a few first-person accounts by some of the visa applicants.

Johnson's narrative is informative, interesting and sometimes even entertaining. Readers will quickly realise, however, that the intended audience is the American public, and that Johnson wanted to achieve something more than merely entertain them. He clearly wrote the book in order to champion the cause referred to in the subtitle - saving the Iraqis America left behind. ${ }^{3}$

\section{Academic utility of Ashcroft and Johnson's narratives}

At least two major reasons may be given for regarding the narratives of Ashcroft and Johnson as useful to researchers and scholars with an interest in contemporary armed conflict. The first is the research value of personal narratives in general. It is a perfectly valid modus operandi for literature-based research to gather information about armed conflict by reading the personal accounts of participants and eyewitnesses. Ashcroft and Johnson's books can be treated as primary sources of information, since the authors wrote mostly about events that they themselves had experienced. Note also that it is possible to regard the narratives of Ashcroft and 
Johnson as examples of auto-ethnography - if one views them from a qualitative research perspective.

Access to the perspectives and the observations of Ashcroft and Johnson is the second major reason why scholars might find their narratives useful. Both authors comment on a number of issues of interest to researchers and scholars with a focus on contemporary armed conflict. Each author enjoyed the benefits of a particular vantage point that qualify him as an authoritative observer and which informed his narrative. Both authors, amongst other things, were able to access information and exploit observation opportunities unavailable to those in other positions.

\section{Ashcroft's perspective}

Ashcroft's vantage point can be characterised as that of someone:

- Who had been an infantry officer in the British Army;

- Who experienced the Iraq war as an employee of Spartan, a PMSC based in the UK;

- Whose job required close contact and cooperation with both Iraqi nationals and American soldiers; and

- Who re-visited Iraq in order to help rescue an Iraqi national who was a friend and former Spartan comrade.

Ashcroft's military career started in 1992 when he attended the Royal Military Academy Sandhurst. A year later he joined the $1^{\text {st }}$ Battalion, Duke of Wellington's Regiment as an infantry platoon commander with the rank of captain. Ashcroft's assignments and tours of duty during the next six years included Bosnia and Northern Ireland, as well as working with US Airborne, US Marines and US Special Forces. Ashcroft resigned his commission in order to return to his original career as a law practitioner, but soon regretted his decision and started daydreaming about re-joining the British Army. Spartan made him an employment offer a month after the invasion of Iraq (19 March 2003). Ashcroft accepted immediately and never regretted his new career choice, ${ }^{4}$ the significance of which should not be underestimated. Ashcroft had already been daydreaming about quitting his job and re-joining his old battalion when the private military industry offered him an alternative military career. This option had not been available to previous generations of soldiers. Furthermore, Ashcroft was offered the job precisely because he had served in the British Army. 
Regarding Ashcroft's experiences in Iraq war as an employee of Spartan, one should keep in mind that PMSCs played a role of unprecedented significance in the Iraq war. According to scholars such as PW Singer and David Isenberg, the US forces could not have operated without private military support. Singer believes the Iraq war to have been a defining moment for the private military industry. ${ }^{5}$

The most obvious implication of point three is that Ashcroft, in his close contact and cooperation with both Iraqi nationals and American soldiers, had access to the views of not only the Americans with whom he came into contact, but also to the views of his Iraqi comrades and acquaintances. His circle of friends included both American soldiers and Iraqi nationals.

The rescue of an Iraqi national, a friend and former Spartan comrade, is significant for a number of reasons. It was a team effort by people who risked their lives voluntarily and without any remuneration. This constitutes behaviour irreconcilable with the traditional image of mercenaries. The rescue team included not only former Spartan colleagues of the Iraqi translator, but also the American colonel who employed Sammy at that stage and who actually initiated the rescue attempt. The reader may ask him/herself why the colonel did not use official channels to save the life of his translator.

The most significant issues commented on by Ashcroft include:

- Private military security companies in Iraq;

- The US military in Iraq;

- The Coalition Provisional Authority in Iraq;

- An Iraqi perspective on the war and its consequences; and

- The Shia-Sunni conflict.

A comprehensive discussion of these issues lies beyond the scope of this review article. Instead, brief mention will be made to some of Ashcroft's more revealing comments.

\section{Ashcroft on private military security companies in Iraq}

It is worth noting how Ashcroft characterises his job at Spartan. He and his comrades were contracted to work as PSDs (personal security details). ${ }^{6}$ Ashcroft describes the work of a PSD as follows, "As PSDs, we don't get paid to kill people. We get paid to protect people, protect the water supply, bodyguard journalists and aid workers, keep our heads down and keep our clients out of trouble."7

What is most significant about this job description is that which is left out. PSDs were not contracted to actively prosecute the war and were not deployed in an 
offensive role. They were employed in a defensive role only - to train people, to protect installations and to bodyguard important individuals. One should keep in mind that every building and every important person guarded by PMSCs was one less for the US Army to protect.

Also noteworthy are Ashcroft's many references to the professionalism and military experience of typical PSDs. The founders of Spartan were ex-military themselves. Ashcroft describes Spartan as "[...] a UK-based outfit set up by a group of ex-officers, one of a clutch of new security firms with savvy bosses aware that the United States didn't have enough boots on the ground". At another point in his narrative, Ashcroft writes,

This is what we were being paid for: for the experience and the training we had in dealing with counter-insurgency and guerrilla tactics. It was good to know that I would be (a) doing work I was good at and (b) working with people who were just as good. ${ }^{9}$

Ashcroft himself had been recruited by a Spartan employee who knew of his professional military background. When he joined Spartan in 2003 there was a large pool of ex-soldiers who did short-term contract work for a relatively small group of companies and many personnel recommendations were based on word of mouth. Successful job seekers not only had to be well-trained and experienced operators, but good team workers as well. At a later stage during the conflict, however, the demand for security personnel increased to the point where some companies were "[...] hiring men by the yard, barely even scanning CVs before offering contracts". 10

In Ashcroft's opinion, most PSDs conducted themselves in a professional and disciplined manner, but a minority did not: "There are on the Circuit some trigger-happy adventurers who shoot and scoot with little provocation, Rambo lookalikes in head-bands with bandoliers of cartridges. Sometimes you come across some cold-blooded killers. But these men are in the minority." "Escape from Baghdad contains a description of the unprofessional conduct of an American civilian contractor team who had been hired to escort a convoy and who had proved to be completely ineffective during an ambush. Before the convoy started, team members had given the impression that they had had little or no combat experience and were more concerned with their appearance than anything else. ${ }^{12}$ One even turned up for the departure of the convoy at 03:00 wearing sunglasses. ${ }^{13}$ 


\section{Ashcroft on the US military in Iraq}

Ashcroft's perspective on the US military and their behaviour is illuminating. His impression of the US military changed greatly during his tour in Iraq. Ashcroft arrived in the country with the idea that the US forces were "triggerhappy thugs". ${ }^{14}$ This impression was based exclusively on media coverage of the war. As a Spartan employee, however, he worked closely with US troops and therefore could base his impression on direct observation. He eventually concluded that (i) only a small minority of the US troops acted like "trigger-happy thugs" and (ii) that the majority of the US troops were "professional, dedicated and sympathetic soldiers doing a tough job under extremely difficult circumstances". ${ }^{15}$

In his first book, Ashcroft describes two incidents that illustrate the type of behaviour by US troops that alienated the local population. The first incident was an encounter by Spartan PSDs with an American vehicular patrol that was following the standard operating procedures in effect at the time. The second incident was an insurgent attack on the checkpoint at a Green Zone gate where a line of vehicles (including those of Spartan) was waiting to be let through. The response of the US guardian force not only demonstrated how the local population was being alienated, but also why 'friendly' fire from the US contingent of the Coalition Forces took out most of the contractors killed at that time (2003). ${ }^{16}$ Ashcroft nevertheless concluded that:

It would be too simplistic to blame insensitive Coalition troops for fanning the flames of the insurgency. [...] As far as I could see as a former infantry officer, the occupation troops had from the start been dealt an awful hand to play by their superiors. ${ }^{17}$

Also illuminating is Ashcroft's account of a "vigorous discussion"18 he had with some US officers. ${ }^{19}$ During that discussion, Ashcroft made himself unpopular by pointing out (i) that most of the US military knew very little about the various insurgent groups and what they were fighting for; (ii) that it is difficult to prevent an enemy from achieving its objectives if you do not know what they are; (iii) that the American soldiers with whom he came into contact, disagreed amongst themselves about what the US military was trying to achieve in Iraq; and (iv) that serious deficiencies qualified all the answers he had received from American soldiers about US objectives in Iraq. It is worth quoting Ashcroft's response when asked whether he himself could give a satisfactory answer to the question:

'I don't know, mate,' I replied cheerfully. 'What I do know is that I should be able to go out there and ask any soldier what he or she's 
fighting for and they should know why they are here. But they don't. [...] And I'm sat here with a bunch of senior officers and they can't tell me why there are American soldiers dying out there everyday. And that, gentlemen, is not right.' ${ }^{20}$

\section{Ashcroft on Iraqi perspectives}

Ashcroft's inclusion in his narrative of the views of some Iraqi acquaintances increases the book's value to researchers and scholars. Ashcroft enjoyed certain advantages when it came to eliciting and understanding the views of his Iraqi associates. As a trainer, he worked closely with Iraqi interpreters and trainees. Furthermore, the Spartan training team was not quartered in a military base (like most of the soldiers) or in the Green Zone (the cordoned-off compound housing the Coalition Provisional Authority and its civilian, non-Iraqi work force). The training team was housed in an abandoned bus depot in the Aradisha Idah neighbourhood of Baghdad, where they came into daily contact with their Iraqi neighbours and even employed some of them. Ashcroft's relationship with some of his Iraqi co-workers and neighbours developed to the point where he could successfully elicit their opinions. These opinions constitute some of the most illuminating and disturbing parts of Ashcroft's narrative, as illustrated by the following quotes.

Ashcroft describes how his Iraqi acquaintances viewed the war as follows:

I was not divorced or isolated from daily life in Baghdad. I was living and working with Iraqis, working class and middle class, from the illiterate to the well educated, and it was depressing listening to their daily tales of loss and fear. None of them, from the highest to the lowest, paid any attention to the international propaganda about the 'Coalition of the Willing'. It was clear to them all that this was a primarily American and partly British occupation. Christian armies were in power in their country and harsh and unforgiving treatment of civilians by Coalition soldiers at checkpoints only brought back memories of the Ba'athist regime. ${ }^{21}$

Ashcroft found the following view of the USA surprising:

Chatting with Sammy and Colonel Faisal over beers through many long evenings brought out a surprising view of the United States from the Iraqi perspective. Although many Iraqis saw the chaos around them as evidence of American incompetence, many former 
military officers, including Sammy and Faisal, dismissed that argument. They thought America was unarguably the most powerful country in the world. [...] It was inconceivable that such a powerful country could let Iraq crumble into medieval anarchy with hundreds of thousands of people living with no utilities, fuel, food or medical aid. [...] To them it was a deliberate plan, orchestrated to punish the Iraqi people. They had no doubt of that, and just wanted to know how much they needed to be punished before this time would end. ${ }^{22}$

The following view that Ashcroft recorded can be considered alarming rather than merely surprising:

No one had liked Saddam because he was a murderous tyrant. [...] By mid-2004, when everyone was heartily sick of the blood and dying, Colonel Faisal confided to me that if Saddam were released and put back in charge, most Iraqis would welcome him. ${ }^{23}$

Upon seeing this passage, the reader may be tempted to ask him/herself whether a worse condemnation of the US-led intervention is possible.

\section{Johnson's perspective on the Iraq war}

Kirk Johnson's vantage point can be characterised as that of someone:

- Who served as an information and public affairs officer in the Baghdad office of USAID;

- Who served in the field as a USAID regional coordinator for reconstruction in Fallujah;

- Who spoke Arabic fluently; and

- Who engaged in a campaign to obtain visas for US-affiliated Iraqi nationals and eventually founded the List Project to Resettle Iraqi Allies.

One implication of the first two points in the list above is that Johnson had an insider's view of both the USAID bureaucracy and the reconstruction effort. Especially significant are the reasons why Johnson became disillusioned with both posts.

One of Johnson's primary responsibilities as a public affairs officer was to find good news about USAID reconstruction projects and to summarise it in a twopage report called the 'Iraq Daily Update' (IDU). The distribution list of the IDU included a large number of bureaucrats, journalists, contractors and US Congress 
members. Johnson became disillusioned with his job as producer of the IDU when he realised that he "[...] was the person in charge of turning out little scraps of propaganda with tenuous ties to reality". ${ }^{24}$

A contributing factor to Johnson's disillusionment was that the language of the IDU was the language of the US government - "USGspeak". ${ }^{25}$ USGspeak, according to Johnson, is a coded language that offers bureaucrats an escape route in case something goes wrong, as well as a trail of bread crumbs in case something goes right and they want to take credit. Johnson's account of USGspeak, including his Glossary of USGspeak, is both informative and entertaining. ${ }^{26}$ At this point in Johnson's narrative, the reader might wonder about the quality of the information that eventually reached planners and decision-makers back in the USA.

Johnson mentions that he embarked on his Fallujah assignment with the hope of contributing something tangible to the reconstruction effort in Iraq, but that he was worried about the meaning of the term 'coordinator' in his new job title regional coordinator for reconstruction in Fallujah. Producing the IDU had shown Johnson how potentially toothless the verb 'to coordinate' could be in USGspeak. ${ }^{27}$

Johnson also mentions that USAID had already allocated roughly $\$ 15$ million for various reconstruction projects in Fallujah before he went there. As a result of the insurgency, however, nobody from the agency had ever been sent to check up on the work. Instead, the USAID mission in Baghdad had relied on one- or two-paged reports emailed periodically by the main contractors involved. Johnson decided to start with a small audit of the projects listed as completed. In view of the circumstances, it is not surprising that he found that "There was waste or fraud in nearly every project I looked at." 28 One of the examples that Johnson gives in this regard involved a fictitious rubble removal project into which millions of dollars had already been poured. Johnson realised that he could request project termination only if he had a worthy replacement ready. The reason why Johnson could not immediately request the termination of the rubble project is illuminating:

I wanted to end the program, to stop wasting the money. This would require crying foul, informing the USAID cognizant technical officers and management back in the Green Zone that their projects, which earned them a lot of favor with the Pentagon and were part of the whole hand-in-glove craze, were bullshit. And if a project didn't exist, it meant that auditors in the Inspector General's Office might catch on and start poking around in other parts of their work. ${ }^{29}$

After his accident and return to America, Johnson learned that USAID had never sent a replacement to Fallujah, that the worthy alternative project (irrigation 
canal clearing) had unravelled and that the project funds had been diverted back to rubble removal. His interpretation of the news is, "Despite all of my efforts, not a single thing remained. It was as if I had never even been there." ${ }^{30}$ The reader may wonder whether the problems that Johnson encountered in Fallujah were the exception or the rule. Widespread waste and fraud would indicate that reconstruction failures in Iraq were due to more than just the insurgency.

Johnson's command of Arabic is the third point in the list at the beginning of this section. When he arrived in Baghdad, Johnson was the only American in the USAID office who could speak Arabic fluently. Johnson's narrative clearly shows that his command of Arabic decisively affected his perspective on the war in Iraq. It also played a major role in the divergence of his views from those of his fellow Americans in the Baghdad offices of USAID. Johnson's command of Arabic and his attitude towards his Iraqi colleagues stood in sharp contrast to those of his fellow Americans in the USAID office. During Johnson's welcome briefing, for example, the supervisor of the 90 Iraqi employees in the office remarked, "Oh, their names are so tricky and hard to remember! Just call them Ahmed or Mohammad, that's what I do, and it sure seems to do the trick." ${ }^{\prime 1}$

Johnson does not delve into the reasons for the attitudes that many of his fellow Americans displayed towards their Iraqi colleagues. He merely mentions increasing distrust as the insurgency progressed. ${ }^{32}$ The reader may ask him/herself whether the attitude towards Iraqi employees as described by Johnson was common in the Department of State bureaucracy in the USA as well. The reader may also wonder whether this attitude had anything to do with the lack of cooperation that Johnson encountered when he tried to arrange visas for American-affiliated Iraqis.

Johnson's campaign to obtain visas for US-affiliated Iraqi nationals is the fourth point in the list at the beginning of this section. His account of this campaign constitutes about half the book. Johnson explains, amongst other things, how and why he embarked on his campaign. He also describes the visa applicants whom he tried to help. They all had at least three things in common:

- They were people whose lives were being threatened by local militias because they had been identified as Iraqis working for the Americans;

- Their American employers in Iraq refused to help; and

- Their applications for American visas were being stalled by the Department of State bureaucracy.

Johnson's account of his visa campaign contains a number of interesting and significant points. The first and most important point is that Johnson, despite all his efforts, failed to change the obstructionist behaviour of the Department of State 
bureaucracy. This was despite the impressive political support that he managed to mobilise. Johnson, for instance, managed to obtain support from Senator Edward ('Ted') Kennedy. ${ }^{33}$ Late in 2007 , Kennedy led a bipartisan coalition of senators in passing the Refugee Crisis in Iraq Act. This act made provision for the granting of 25000 immigration visas specifically to US-affiliated Iraqis over a period of five years. Near the end of that period (in 2013), about 18000 of these visas had not been issued. ${ }^{34}$ It should further be noted that the bureaucracy maintained their stance despite the replacement of the Bush administration with that of Obama.

Another reason for regarding Johnson's account as interesting and informative is that he found historical precedents for the stalling of visa applications by US-affiliated foreign nationals. Something similar happened at the end of both the Second World War and the Vietnam War. ${ }^{35}$

Johnson's remarks about USGspeak constitute a further reason for regarding his account as interesting and informative. The account contains many examples of USGspeak by Department of State bureaucrats. Readers should find it interesting to compare what was said (or implied) at the time with what was actually happening. ${ }^{36}$ Readers might even be tempted to take it one step further and compare the relationship between 'truth' and 'USG speak' to the relationship between 'truth' and 'Newspeak', as used by George Orwell in his novel Nineteen eighty-four, first published in 1949.

In conclusion, the books should be useful to researchers and scholars with an interest in contemporary armed conflict. The value of the books lies in the perspectives of the authors.

\section{Endnotes}

${ }^{1}$ The team included a few South African ex-soldiers.

${ }^{2}$ Ashcroft, J. Making a killing: The explosive story of a hired gun in Iraq. London: Virgin Books, 2010, 141; Ashcroft, J. Escape from Baghdad. London: Virgin Books, 2009, 3, 17-20, 64-77, 99-100.

${ }^{3}$ Johnson, KW. To be a friend is fatal: The fight to save the Iraqis America left behind. New York: Scribner, 2013, v. See also the website of the List Project at <http://thelistproject.org/about-the-list-project/> Accessed on 7 January 2014.

${ }^{4}$ Ashcroft, Making a killing op. cit. pp. 1-6; Ashcroft, Escape from Baghdad op. cit. pp. 1-3.

${ }^{5}$ Singer, PW. Corporate warriors: The rise of the privatized military industry (updated edition). Ithaca, NY: Cornell University Press, 2008, 248-243; Isenberg, D. Shadow force: Private security contractors in Iraq. Westport: Praeger Security International, 2009, ix-xii, 29-66. 
${ }^{6}$ Ashcroft, Escape from Baghdad op. cit., p. xiii. The abbreviation PSD is used as both a noun and a verb.

${ }^{7}$ Ibid., pp. 47, 330-331.

${ }^{8}$ Ashcroft, Making a killing op. cit., p 3.

${ }^{9}$ Ibid., p. 68.

${ }^{10}$ Ibid., p. 69.

${ }^{11}$ Ashcroft, Escape from Baghdad op. cit., p. 47.

${ }^{12}$ Ibid., pp. 155-162.

${ }^{13}$ Ibid., p. 158.

${ }^{14}$ Ashcroft, Making a killing op. cit., p. 288.

${ }^{15}$ Ibid., pp. 287-288. See also the Ashcroft's website at <http://www.makingakilling.co.uk/book.html> Accessed on 7 January 2014. Ashcroft's answers under the heading FAQ are especially informative. Among other things, Ashcroft provides censored photographs of himself, his comrades and Mashoen.

${ }^{16}$ Ashcroft, Making a killing op. cit., pp. 6, 7, 27-50.

${ }^{17}$ Ibid., p. 291.

${ }^{18}$ Ibid., p. 294.

${ }^{19}$ Ibid., pp. 294-303.

${ }^{20}$ Ibid., p. 303.

${ }^{21}$ Ibid., p. 288.

${ }^{22}$ Ibid., pp. 288-289.

23 Ibid., p. 290.

${ }^{24}$ Johnson op. cit., p. 53.

${ }^{25}$ Ibid., p. 51.

${ }^{26}$ Ibid., pp. 52, 53, 315.

${ }^{27}$ Ibid., p. 77.

${ }^{28}$ Ibid., p. 90.

${ }^{29}$ Ibid., p. 90.

${ }^{30}$ Ibid., pp. 129-130.

${ }^{31}$ Ibid., p. 46.

${ }^{32}$ Ibid., pp. 62-66.

${ }^{33}$ Ibid., pp. 192-193, 238, 242, 244-246, 302-303.

${ }^{34}$ Ibid., p. 302.

${ }^{35}$ Ibid., pp. 265-274. Johnson recorded his finding in a report titled "A history of just and unjust withdrawals", published on the List Project website at <http://thelistproject.org/history/> Accessed on 7 January 2014.

${ }^{36}$ See the statements recorded on pages $273-274$, for example. 